\title{
Tindakan vandalisme di Perpustakaan Fakultas Ilmu Komunikasi Universitas Padjadjaran
}

\author{
Ilham Nur Muhammad1, Neneng Komariah², Nuning Kurniasih ${ }^{3}$ \\ ${ }^{1}$ Cakrawala Andalas Televisi (ANTV) \\ Komplek Rasuna Epicentrum Lot 9 Jl. H.R. Rasuna Said, Jakarta Selatan, DKI Jakarta, Indonesia 12940 \\ 2,3Program Studi Ilmu Perpustakaan, Universitas Padjadjaran \\ Jl. Raya Bandung-Sumedang Km. 21, Jatinangor, Sumedang, Jawa Barat, Indonesia 45363 \\ Email: 1ilhamnm34@gmail.com, ${ }^{2}$ neneng.komariah@unpad.ac.id, ${ }^{3}$ nuning.kurniasih@unpad.ac.id
}

Received: Juli 2018; Accepted: June 2019; Published: June 2019

\begin{abstract}
The library is prone to vandalism towards library collections. The Faculty of Communication Sciences library as a university library often experiences vandalism, ranging from labeling, tearing up, page folding, delay in returning books, and loss of books. This study aimed to determine the cognitive aspects of the sub-variables of knowledge and understanding of users on the act of vandalism in the Library of the Faculty of Communication Sciences, Padjadjaran University. The research method used descriptive survey method through a quantitative approach. This study included 121 respondents consisting of students of Faculty of Communication Sciences, class of 2015 who were selected using simple random sampling technique with distribution of respondent composition: Public Relations 10 respondents, Communication Sciences 47 respondents, Information and Library Science 22 respondents, Journalism 16 respondents, Communication Management 18 respondents, and TV and Film 8 respondents. Study results showed that the cognitive aspects of the users in the act of vandalism were in the category of high and favorable, the users had knowledge and understanding which supported according to the statement about the attitude proposed against acts of vandalism. Based on knowledge indicators, data obtained showed respondents did not agree with vandalism act, while based on the indicators of understanding, data obtained showed respondents agree that vandalism could harm the library users. Overall, the attitude of users is in the favorable category meaning that library users support disagreement on vandalism in the Library of the Faculty of Communication Sciences, Padjadjaran University.
\end{abstract}

Keywords: Cognitive response; Vandalism; Library user's attitude

\begin{abstract}
Abstrak
Perpustakaan rentan terjadinya tindakan vandalisme terhadap koleksi perpustakaan. Perpustakaan Fakultas Ilmu Komunikasi sebagai perpustakaan universitas sering terjadinya tindakan vandalisme, mulai dari penandaan tulisan, perobekan, pelipatan halaman, keterlambatan pengembalian buku, dan kehilangan buku. Maka, penelitian ini bertujuan untuk mengetahui aspek kognitif dari sub variabel pengetahuan dan pemahaman pemustaka pada tindakan vandalisme di Perpustakaan Fakultas Ilmu Komunikasi Universitas Padjadjaran. Metode penelitian yang digunakan adalah metode survei deskriptif melalui pendekatan kuantitatif. Penelitian ini dilakukan kepada responden penelitian sebanyak 121 orang mahasiswa Fakultas Ilmu Komunikasi Universitas Padjadjaran angkatan 2015 yang dipilih menggunakan teknik simple random sampling dengan pembagian komposisi mahasiswa Hubungan Masyarakat 10 responden, mahasiswa Ilmu Komunikasi 47 responden, mahasiswa Ilmu Informasi dan Perpustakaan 22 responden, mahasiswa Jurnalistik 16 responden, mahasiswa Manajemen Komunikasi 18 responden, mahasiswa TV dan Film 8 responden. Hasil penelitian menunjukkan bahwa dalam aspek kognitif pemustaka pada tindakan vandalisme berada pada kategori tinggi dan baik (favorable), pemustaka mempunyai pengetahuan dan pemahaman yang mendukung sesuai dengan pernyataan mengenai sikap yang diajukan terhadap tindakan vandalisme. Sesuai indikator pengetahuan diperoleh data responden tidak setuju terhadap beberapa tindakan vandalisme, sedangkan sesuai indikator pemahaman diperoleh juga data responden yang setuju bahwa beberapa tindakan vandalisme dapat merugikan pemustaka di perpustakaan. Secara keseluruhan, sikap pemustaka berada pada kategori baik artinya pemustaka mendukung sikap tidak setuju terhadap tindakan vandalisme di Perpustakaan Fakultas Ilmu Komunikasi Universitas Padjadjaran.
\end{abstract}

Kata Kunci: Respon kognitif; Vandalisme; Sikap pemustaka 


\section{PENDAHULUAN}

Perpustakaan menjadi lembaga informasi yang membantu di keseharian kita. Perpustakaan tidak hanya tersedia pada unit pendidikan saja melainkan ada di berbagai sektor masyarakat. Perpustakaan menyediakan beragam informasi yang disesuaikan kebutuhan para pengguna perpustakaan. Perpustakaan menyediakan beragam jenis koleksi untuk memenuhi beragam kebutuhan informasi para pemustaka. Hal ini dapat membuat perpustakaan memiliki berbagai macam fungsi lain guna menyesuaikan dengan isi koleksi yang dimiliki.

Perpustakaan perguruan tinggi merupakan perpustakaan yang memiliki koleksi sesuai bidang keilmuan di tiap fakultas, di antaranya buku, koran, majalah, kamus, karya ilmiah serta koleksi elektronik seperti e-journal, e-book dan e-resources lainnya. Perpustakaan perguruan tinggi, sama halnya dengan berbagai jenis perpustakaan lainnya memiliki permasalahaan mengenai penyalahgunaan koleksi. Obiagwu (1992) dalam Damayanti, Sukaesih and Rainathami (2015) menulis, “Tindakan penyalahgunaan koleksi dikelompokkan ke dalam empat jenis yaitu pencurian (theft), mutilasi (mutilation), peminjaman tidak sah (unauthorized borrowing), dan vandalisme (vandalism)."

Tindakan vandalisme yaitu, “Tindakan perusakan bahan pustaka melalui menyobek, membakar, membasahi dan lain-lain. Mengenalkan virus secara sengaja pada program komputer atau menekan disket database juga termasuk ke dalam tindakan vandalisme" (Damayanti, Sukaesih, \& Rainathami, 2015). Tindakan vandalisme di perpustakaan dapat terjadi karena dipicu kurangnya pengetahuan pemustaka mengenai tindakan apa saja yang termasuk ke dalam tindakan vandalisme.

Tindakan vandalisme pun terjadi di Perpustakaan Fakultas Ilmu Komunikasi (FIKOM) Universitas Padjadjaran (UNPAD). Berdasarkan hasil wawancara dengan kepala perpustakaan didapatkan fakta sejauh ini bahwa tindakan vandalisme yang sering terjadi di perpustakaan berupa pemberian tanda pada kertas menggunakan stabillo atau ballpoint, pelipatan halaman, terlambatnya pengembalian buku, bahkan yang terparah adalah penghilangan satu bab penuh pada sebuah buku (Y. Yulianti, wawancara, Desember 1, 2018).

Aina (2004) dalam Adekunle, Adekunjo, and Unuabor (2018) menyatakan bahwa perpustakaan universitas berfungsi, "To support the objectives of the university in the area of learning, teaching, research and community service". Perpustakaan universitas harus berperan sebagai lembaga pengetahuan yang menyediakan wilayah untuk belajar, pengajaran, penelitian, dan pelayanan bagi dosen, mahasiswa dan staf universitas. Namun, apabila tindakan vandalisme terjadi dalam koleksi perpustakaan, maka kegiatan belajar, pengajaran, penelitian dan pelayanan lainnya akan terhambat.

Pustakawan di Perpustakaan FIKOM UNPAD, memberikan teguran secara lisan pada pelaku tindakan vandalisme. Kerugian atas tindakan vandalisme sejauh ini ditangani sendiri oleh pustakawan. Buku yang masih dapat diperbaiki akan diperbaiki langsung, sedangkan yang sudah mengalami kerusakan parah akan disimpan di ruangan khusus. Sejauh ini, pustakawan pernah melaporkan tindakan vandalisme berupa pencurian buku kepada Dekan FIKOM sehingga pelakunya diberikan teguran secara lisan agar tidak mengulangi perbuatannya kembali. Walaupun begitu, 
dari tindakan vandalisme di atas, ternyata telah membuat koleksi perpustakaan yang disedang dicari pemustaka tidak bisa diakses. Proses belajar dan pengajar pun menjadi terganggu.

Berdasarkan hal tersebut, terlihat bahwa di perpustakaan perguruan tinggi rentan terjadinya tindakan vandalisme. Penelitian yang dilakukan oleh Rahmawati (2014) menunjukkan bahwa,

“Tindakan vandalisme yang terjadi di Perpustakaan Pusat UIN Syarif Hidayatullah Jakarta, di antaranya ialah, pemustaka berjumlah $82,97 \%$ pernah menandai buku perpustakaan dengan berbagai cara, pemustaka berjumlah $24,46 \%$ mengaku pernah mencoret-coret buku koleksi perpustakaan, pemustaka berjumlah $36,17 \%$ pernah melihat teman atau pengunjung lain mencoret-coret buku koleksi perpustakaan."

Kegiatan vandalisme yang banyak dilakukan pengguna Perpustakaan Pusat UIN Syarif Hidayatullah Jakarta ialah menandai buku perpustakaan, bisa melalui stabillo, pulpen, pensil hingga tipe-x. Jika diurutkan, tindakan vandalisme di Perpustakaan FIKOM UNPAD yaitu tindakan unauthorized borrowing, vandalisme, pencurian, dan mutilasi. Tindakan penyalahgunaan koleksi ini merugikan bagi perpustakaan dan pemustaka lain karena mengakibatkan pembengkakan anggaran untuk memperbaiki koleksi yang rusak atau mengganti koleksi tersebut dengan yang baru. Koleksi di Perpustakaan FIKOM UNPAD tidak luput dari pelaku tindakan vandalisme. Hal tersebut dapat dilihat dari beberapa koleksi yang halamannya terlipat, terdapat coretan stabillo atau ballpoint, serta berbagai bentuk tindakan lainnya.
Tindakan vandalisme

di Perpustakaan FIKOM UNPAD sangat merugikan banyak pihak, yakni dari pihak perpustakaan dan pemustaka lainnya. Perpustakaan harus membeli kembali koleksi yang hilang. Apabila koleksi yang hilang tersebut tidak diterbitkan kembali di penerbitan, maka perpustakaan harus mencari buku tersebut di toko buku kecil, toko buku bekas atau melalui pembelian di website. Tentunya, dari segi ekonomi, hal ini menambah pengeluaran perpustakaan. Padahal, perpustakaan hanya membeli koleksi buku setahun sekali saja. Itu pun, perpustakaan harus mengajukan pengadaan buku melalui proses yang rumit dan panjang.

Selain itu, akibat tindakan vandalisme, perpustakaan harus memperbaiki koleksi yang rusak. Perbaikan koleksi buku berbeda penanganannya sesuai jenis kerusakan yang dialaminya. Pertama, kasus halaman yang hilang. Perpustakaan harus memperbanyak halaman buku yang hilang, di mana diambil dari buku yang berjudul sama. Namun, apabila bukunya hanya satu eksemplar, maka perpustakaan mencari electronic book (e-book) lalu mencetak halaman yang dibutuhkan, atau mencari buku tersebut ke perpustakaan yang lain. Kedua, kasus jilid buku yang rusak. Staf perpustakaan harus memperbaiki sendiri dengan memberikan lem, menjahit kertas bagian sampul depan, atau menggunakan jasa fotokopi. Ketiga, kasus kertas buku yang terkena air. Perpustakaan harus mengulasi kapur ke dalam tiap halaman lalu menjemurnya. Berdasarkan dampak negatif tindakan vandalisme di atas, Perpustakaan FIKOM UNPAD harus mengeluarkan biaya untuk pengadaan koleksi kembali dan memperbaiki buku yang rusak. Padahal, perpustakaan dalam mengeluarkan biaya 
kebutuhan buku harus melalui pengajuan terlebih dahulu, sehingga terkadang perpustakaan membiayai koleksi yang hilang atau rusak dari kas perpustakaan.

Selain itu, dari pihak pemustaka, tindakan vandalisme sangat menyulitkan pemustaka untuk mendapatkan koleksi yang sedang dicarinya. Sebagai contoh, ada mahasiswa tingkat akhir yang membutuhkan satu buku sebagai teori utama. Buku tersebut hanya satu eksemplar di perpustakaan, dan bila dicari melalui media online tidak terdapat bentuk electronic book. Kisah lain, buku tersebut ada di perpustakaan namun kondisi halamannya hilang atau sobek, maka pemustaka tidak bisa membacanya. Dari hal ini, muncul ketidakpuasan dari pemustaka terhadap perpustakaan. Pemustaka tidak bisa mengakses kebutuhan informasi yang sedang dicarinya.

Sebenarnya, Perpustakaan FIKOM UNPAD pernah menggunakan RFID (Radio Frequency Identification) sebagai sistem keamanan perpustakaan. Pustakawan ketika mengolah koleksi buku mengintegrasikan database dengan sistem RFID, lalu tiap buku ditempelkan barcode atau chip RFID.

Ketika RFID digunakan di Perpustakaan FIKOM UNPAD, telah mengurangi tindakan vandalisme. Setiap buku yang akan dicuri, akan ketahuan oleh pustakawan. Lalu perpustakaan pun memasang CCTV di ruangan membaca untuk mengetahui pemustaka yang merusak koleksi buku. Namun, penggunaan RFID dan CCTV tidak berlangsung lama di perpustakaan. Ketika sistem katalog elektronik mulai disatukan di tingkat universitas, Perpustakaan FIKOM UNPAD pun harus memperbarui data dan chip dalam koleksi bukunya. Selain itu, terkadang RFID mengalami kerusakan sehingga proses sirkulasi koleksi buku terhambat karena pustakawan harus menunggu lama staf khusus IT.

Sesuai pemaparan di atas, tindakan vandalisme memberikan dampak negatif bagi Perpustakaan FIKOM UNPAD. Padahal, pemustaka dapat menemukan informasi mengenai akses koleksi buku di pelbagai sumber sehingga pemustaka dapat teralihkan dari tindakan vandalisme. Maka, penelitian ini difokuskan untuk mengetahui sikap para pemustaka di Perpustakaan FIKOM UNPAD dalam aspek kognitif terhadap tindakan vandalisme. Aspek kognitif menjadi salah satu komponen utama dalam terbentuknya sikap pemustaka sehingga harus diteliti lebih lanjut. Berdasarkan beberapa tindakan vandalisme yang terjadi di perpustakaan, peneliti tertarik untuk mengetahui apa saja tindakan vandalisme yang terjadi serta bagaimana sikap pemustaka dalam menanggapi adanya vandalisme di Perpustakaan FIKOM UNPAD.

\section{METODE PENELITIAN}

Penelitian ini menggunakan metode penelitian survei melalui pendekatan kuantitatif. Penelitian survei menurut Singarimbun (1989) dalam Kisti and Fardana (2012) ialah, "Penelitian yang mengambil sampel dari suatu populasi dengan menggunakan kuesioner sebagai alat pengumpul data yang pokok." Maka, metode penelitian survei yang dipergunakan yaitu metode survei deskriptif.

Singarimbun (1989) dalam Kisti and Fardana (2012) pun menyatakan kembali, "Metode survei deskriptif adalah untuk mengukur dengan cermat fenomena sosial tertentu di mana peneliti mengembangkan konsep serta menghimpun fakta namun tidak menguji hipotesis." Kegunaan dari 
penelitian survei lebih kepada evaluasi pada objek penelitian sendiri. Tujuan penelitian ini adalah untuk mengetahui aspek kognitif pemustaka pada tindakan vandalisme.

Sub variabel aspek kognitif pemustaka pada tindakan vandalisme memiliki 2 indikator, di antaranya pengetahuan dan pemahaman. Indikator pengetahuan memiliki 7 pertanyaan. Pertama, pertanyaan mengenai pengetahuan pemustaka tentang pengeratan dan membetot halaman. Kedua, pertanyaan mengenai pengetahuan pemustaka tentang perobekan halaman tertentu. Ketiga, pertanyaan mengenai pengetahuan pemustaka tentang pengguntingan gambar. Keempat, pertanyaan mengenai pengetahuan pemustaka tentang coretan tulisan dan penanda. Kelima, pertanyaan mengenai pengetahuan pemustaka tentang pelipatan halaman tertentu. Keenam pertanyaan mengenai pengetahuan pemustaka tentang pemanfaatan kartu anggota orang lain.

Indikator pemahaman pun memiliki 7 pertanyaan. Pertama, pertanyaan mengenai pemahaman pemustaka tentang pengeratan dan membetot halaman. Kedua, pertanyaan mengenai pemahaman pemustaka tentang perobekan halaman tertentu. Ketiga, pertanyaan mengenai pemahaman pemustaka tentang pengguntingan gambar. Keempat, pertanyaan mengenai pemahaman pemustaka tentang coretan tulisan dan penanda. Kelima, pertanyaan mengenai pemahaman pemustaka tentang pelipatan halaman tertentu. Keenam pertanyaan mengenai pemahaman pemustaka tentang pemanfaatan kartu anggota orang lain.

Subjek yang diteliti dalam penelitian ini yakni mahasiswa FIKOM UNPAD angkatan 2015 yang diberikan angket.
Kemudian data hasil angket akan diolah lalu dihitung. Selanjutnya hasil perhitungan tersebut dianalisis dan dijelaskan secara deskriptif. Populasi mahasiswa aktif angkatan 2015 sebanyak 678 mahasiswa. Metode pengambilan sampel yang diterapkan menggunakan metode probability sampling dan menggunakan teknik simple random sampling. Ridwan and Kuncoro (2012) dalam Muhammad mengatakan bahwa teknik ini berupa,

"Pengambilan Sampel dari anggota populasi secara acak dan berstrata tetap sebagian yang kurang porporsional pembagiannya, dilakukan sampling ini apabila anggota populasi heterogen (tidak sejenis)."

Sampel penelitian yang diambil sebanyak 121 responden dengan pembagian secara merata didapatkan dari hasil responden tiap program studi, di antaranya Program Studi Hubungan Masyarakat sebanyak 10 responden, Program Studi Ilmu Komunikasi sejumlah 47 responden, Program Studi Ilmu Perpustakaan sebanyak 22 responden, Program Studi Jurnalistik sejumlah 16 responden, Program Studi Manajemen Komunikasi sejumlah 18 responden, dan Program Studi TV dan Film sebanyak 8 responden. Pengumpulan data penelitian dilakukan dengan melakukan penyebaran kuesioner kepada para responden, wawancara pada sumber terpercaya, observasi ke lapangan, serta studi pustaka yang dilakukan pada Bulan Desember 2017 hingga Januari 2018. Analisis data dilakukan secara deskriptif. Rakhmat (2009) menambahkan bahwa,

"Metode deskriptif memaparkan situasi atau peristiwa, tanpa mencari atau menjelaskan hubungan, tidak menguji hipotesis atau membuat prediksi." 


\section{HASIL DAN PEMBAHASAN}

Sikap seorang individu menjadi fokus utama pembahasan dalam penelitian ini. Dasar pemahaman sikap diambil dari skema triadik, yakni sikap terdiri dari aspek kognitif, afektif, dan konatif dalam diri setiap individu. Azwar (2011) dalam Andina (2016) menyebutkan ketiga sikap ini di antaranya,

“Aspek kognitif (cognitive), aspek afektif (affective) dan aspek konatif (conative)". Didukung komponen kognitif yang merupakan representasi apa yang dipercayai oleh individu pemilik sikap, komponen afektif merupakan perasaan yang menyangkut aspek emosional dan komponen konatif merupakan aspek kecenderungan berperilaku tertentu sesuai dengan sikap yang dimiliki oleh seseorang."

Berdasarkan hal ini, peneliti memahami bahwa sikap merupakan suatu cara bagaimana seorang individu memberikan respons terhadap stimulus dari objek lain. Respons yang diberikan seorang individu dapat beragam bentuk. Salah satunya ialah bentuk keberpihakan atau dukungan terhadap suatu stimulus yang diterima. Hal ini, stimulus yang akan diberikan kepada individu berupa tindakan vandalisme yang nantinya akan dilihat berdasarkan aspek kognitif, afektif dan konatif, dan bagaimana respon individu tersebut terhadap tindakan vandalisme.

Peneliti memfokuskan menganalisis aspek kognitif pada tindakan vandalisme. Peneliti menggunakan teori respon kognitif untuk menganalisis penelitian ini. Aaker and Myers (1992) dalam Winiratih (2016) dalam gambar 1, menyatakan bahwa dalam teori ini, komunikan atau pengguna terlibat aktif dalam proses penerimaan pesan dengan konteks pengetahuan dan sikap yang sudah dimilikinya sehingga terjadi perubahan sikap. Respon kognitif merupakan suatu proses berpikir secara aktif atau aktifitas kognitif yang berlangsung pada saat atau sesudah terjadinya proses komunikasi.

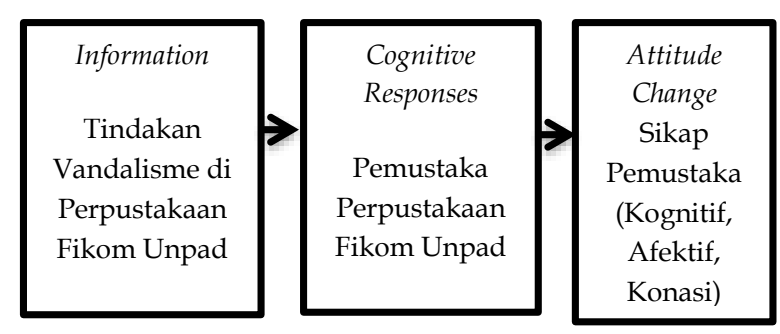

Gambar 1. Teori respon kognitif

Sumber: Adaptasi penulis berdasarkan Aaker dan Myers (1992) dalam Winiratih (2016)

Tindakan vandalisme di perpustakaan kerap kali terjadi pada koleksi perpustakaan. Menurut Sinaga (2005) dalam Astriyana (2017), koleksi perpustakaan ialah,

"Keseluruhan bahan pustaka yang dibina dan dikumpulkan oleh suatu perpustakaan melalui suatu pembelian, sumbangan, pertukaran, atau membuat sendiri dengan tujuan untuk disajikan dan didayagunakan [berdaya guna] oleh seluruh pemakai perpustakaan".

Hal ini ditambahkan Obiagwu (1992) dalam Damayanti et al. (2015) bahwa tindakan vandalisme terhadap koleksi, di antaranya, "Pencurian, mutilasi, peminjaman tidak sah, dan vandalisme."

Tindakan pencurian bisa digolongkan ke dalam pencurian skala kecil dan juga skala besar serta cara peminjam melakukan kecurangan dengan menggunakan kartu anggota perpustakaan curian. Tindakan pencurian koleksi di perpustakaan dilakukan melalui cara menyelinap keluar perpustakaan secara diam-diam, melempar buku keluar jendela, menggunakan pintu lain untuk keluar 
perpustakaan dibanding pintu utama, meminjam koleksi perpustakaan kemudian melaporkan bahwa koleksi tersebut hilang saat waktu pengembalian, menyembunyikan dalam tas, meminjam koleksi dengan kartu anggota perpustakaan curian, memberi cap palsu, mengganti slip peminjaman buku dengan yang palsu, dan bekerja sama dengan pustakawan sirkulasi.

Lalu kegiatan kedua, ialah mutilasi. Reitz (2014) berkata bahwa mutilasi yakni,

"Damage, defacement, or destruction of library materials inflicted intentionally, rather than accidentally, including tearing covers and pages; cutting out illustrations or passages of text; and removing labels, bookplates, protective covers, date due slips, etc.--all actions that drain library resources. The motives for such acts range from an attitude of entitlement, to monetary concerns (libraries generally charge for photocopying), to disapproval of the library's collection development decisions, and outright malice".

Tindakan mutilasi terhadap buku merupakan tindakan yang menimbulkan kerusakan terhadap bahan pustaka yang ditimbulkan secara sengaja bukan secara tidak sengaja. Tindakan mutilasi yang dilakukan berupa merobek penutup dan halaman buku, memotong ilustrasi dan beberapa bagian teks, serta menghilangkan label, menghilangkan cover pelindung buku dan slip kartu peminjaman dan lain-lain. Seluruh kegiatan ini dilakukan untuk menguras sumber daya perpustakaan.

Selanjutnya, Obiagwu (1992) dalam Damayanti, Sukaesih \& Rainathami (2015) menambahkan bahwa, "Mutilation is the excision of articles and ilustrations from journals, books, encyclopedias, etc.". Mutilasi adalah tindakan pembedahan terhadap artikel dan ilustrasi dalam jurnal, buku, ensiklopedi dan lain-lain. Selain itu, kegiatan vandalisme lainnya ialah,

"Peminjaman tidak sah (unauthorized borrowing) dan kegiatan pemustaka yang melanggar aturan peminjaman bahan pustaka" (Damayanti et al., 2015).

Kedua aktivitas ini merupakan peminjaman koleksi perpustakaan tidak melalui proses peminjaman koleksi perpustakaan. Selain itu, tindakan yang melanggar peraturan perpustakaan, misalnya peminjaman koleksi perpustakaan yang telah melebihi lamanya peminjaman. Obiagwu (1992) dalam Damayanti, Sukaesih \& Rainathami ( 2015) memperjelas bahwa vandalisme merupakan tindakan perusakan bahan pustaka dengan cara menyobek, membakar, membasahi dan lainlain. Pemustaka yang menggunakan fasilitas perpustakaan lalu menyebarkan virus komputer secara sengaja juga termasuk ke dalam tindakan vandalisme.

Di sisi lain, Reitz

menyebutkan bahwa vandalisme adalah tindakan perusakan koleksi perpustakaan, peralatan, atau fasilitas perpustakaan secara sengaja atau biasanya didasari motivasi kemarahan dan kebencian dari pelakunya. Fatmawati (2007) dalam Efriza, Agustini and Saepudin (2015) memaparkan ada 7 bentuk vandalisme yang terjadi di perpustakaan, di antaranya

"Pengeratan dan membetot halaman pada koleksi perpustakaan, perobekan pada halaman tertentu, pengguntingan pada gambargambar tertentu, segala bentuk coret-coret tulisan atau penandaan yang menggunakan ballpoint, spidol, stabillo, maupun pensil warna, pelipatan halaman tertentu pada buku, pemanfaatan kartu anggota perpustakaan milik orang lain, serta 
buku yang tidak dikembalikan melebihi batas tempo pengembalian".

Berdasarkan hasil penelitian, aspek kognitif pemustaka berhubungan erat dengan kegiatan vandalisme di perpustakaan. Aspek kognitif pemustaka, dianalisis ke dalam indikator pengetahuan dan pemahaman. Indikator pengetahuan terdiri dari pengetahuan pengeratan dan membetot halaman pada koleksi buku, perobekan halaman tertentu pada koleksi buku, pengguntingan gambar pada koleksi buku, pencoretan berupa tulisan atau penanda pada koleksi buku, pelipatan halaman tertentu pada koleksi buku, pemanfaatan kartu anggota perpustakaan orang lain untuk meminjam koleksi buku, dan pengembalian buku yang terlambat.

\section{Tabel 1}

Pengeratan dan membetot halaman pada koleksi buku

\begin{tabular}{llll}
\hline No. & Kategori jawaban & $\mathbf{f}$ & $\mathbf{\%}$ \\
\hline 1 & Sangat Setuju & 1 & 0,8 \\
2 & Setuju & 27 & 22 \\
3 & Netral & 42 & 35 \\
4 & Tidak Setuju & 35 & 29 \\
5 & Sangat Tidak Setuju & 16 & 13,2 \\
Jumlah & 121 & 100 \\
\hline
\end{tabular}

Sumber: Hasil pengolahan data, 2017

Sesuai tabel 1, diketahui bahwa jawaban responden terhadap pernyataan "Pengetahuan adanya pengeratan dan membetot halaman pada koleksi buku" sebanyak 42 responden memilih jawaban netral, 35 responden memilih jawaban tidak setuju, 27 responden memilih jawaban setuju, 16 responden memilih jawaban sangat tidak setuju dan 1 responden memilih jawaban sangat setuju. Berdasarkan hasil jawaban tersebut, responden tidak mengetahui tindakan pengeratan dan membetot halaman tertentu pada koleksi buku terjadi di Perpustakaan FIKOM UNPAD. Hal ini dikarenakan jawaban responden lebih banyak mengacu ke pernyataan tidak setuju. Jawaban netral responden mengacu pada jawaban tidak tahu jika terjadi atau tidak setuju pada pernyataan tapi ragu-ragu.

Tabel 2

Perobekan halaman tertentu pada koleksi buku

\begin{tabular}{llll}
\hline No. & Kategori jawaban & $\mathbf{f}$ & $\mathbf{\%}$ \\
\hline 1 & Sangat Setuju & 2 & 1,6 \\
2 & Setuju & 18 & 15 \\
3 & Netral & 39 & 32,2 \\
4 & Tidak Setuju & 39 & 32,2 \\
5 & Sangat Tidak Setuju & 23 & 19 \\
Jumlah & 121 & 100 \\
\hline
\end{tabular}

Sumber: Hasil pengolahan data, 2017

Sesuai tabel 2, diketahui bahwa jawaban responden terhadap pernyataan "Perobekan halaman tertentu pada koleksi buku" sebanyak 39 responden memilih jawaban netral dan tidak setuju, 23 responden memilih jawaban sangat tidak setuju, 18 responden memilih jawaban setuju, dan 2 responden memilih jawaban sangat setuju. Berdasarkan hasil jawaban tersebut, responden tidak mengetahui tindakan perobekan halaman tertentu pada koleksi buku terjadi di Perpustakaan FIKOM UNPAD. Hal ini dikarenakan jawaban responden lebih banyak mengacu ke pernyataan tidak setuju. Jawaban netral responden mengacu pada jawaban tidak tahu jika terjadi atau tidak setuju pada pernyataan tapi ragu-ragu. Bello (1991) dalam Listiyani (2010) mengungkapkan bahwa,

"Informasi yang dimuat dalam majalah pasti lebih mutakhir daripada informasi dalam bentuk lain seperti buku sehingga koleksi ini rawan untuk digunting oleh pemustaka." 
Tabel 3

Pengguntingan gambar pada koleksi buku

\begin{tabular}{llll}
\hline No. & Kategori jawaban & f & \% \\
\hline 1 & Sangat Setuju & 2 & 1,6 \\
2 & Setuju & 9 & 7,4 \\
3 & Netral & 31 & 26 \\
4 & Tidak Setuju & 51 & 42 \\
5 & Sangat Tidak Setuju & 28 & 23 \\
Jumlah & 121 & 100 \\
\hline
\end{tabular}

Sumber: Hasil pengolahan data, 2017

Sesuai tabel 3, diketahui bahwa jawaban responden terhadap pernyataan "Pengguntingan gambar pada koleksi buku" sebanyak 51 responden memilih jawaban tidak setuju, 31 responden memilih jawaban netral, 28 responden memilih jawaban sangat tidak setuju, 9 responden memilih jawaban setuju, dan 2 responden memilih jawaban sangat setuju. Berdasarkan hasil jawaban tersebut, responden tidak mengetahui tindakan pengguntingan gambar pada koleksi buku terjadi di Perpustakaan FIKOM UNPAD. Hal ini dikarenakan jawaban responden lebih banyak mengacu ke pernyataan tidak setuju. Jawaban netral responden mengacu pada jawaban tidak tahu jika terjadi atau tidak setuju pada pernyataan tapi raguragu. Sulistyo-Basuki (1991) dalam Listiyani (2010) mengungkapkan bahwa informasi yang dimuat dalam majalah pasti lebih mutakhir daripada informasi dalam bentuk lain seperti buku sehingga koleksi ini rawan untuk digunting pemustaka.

Tabel 4

Pencoretan berupa tulisan atau penanda pada koleksi buku

\begin{tabular}{llll}
\hline No. & Kategori jawaban & $\mathbf{f}$ & $\mathbf{0}$ \\
\hline 1 & Sangat Setuju & 44 & 36,3 \\
2 & Setuju & 48 & 39,6 \\
3 & Netral & 17 & 14 \\
4 & Tidak Setuju & 5 & 4,1 \\
5 & Sangat Tidak Setuju & 7 & 6 \\
Jumlah & 121 & 100 \\
\hline
\end{tabular}

Sumber: Hasil pengolahan data, 2017
Sesuai tabel 4, diketahui bahwa jawaban responden terhadap pernyataan "Adanya coretan baik berupa tulisan atau penanda menggunakan ballpoint/ spidol/ stabillo/ pensil warna pada koleksi buku" sebanyak 48 responden memilih jawaban setuju, 44 responden memilih jawaban sangat setuju, 17 responden memilih jawaban netral, 7 responden memilih jawaban sangat tidak setuju, dan 5 responden memilih jawaban tidak setuju. Berdasarkan hasil jawaban tersebut, responden mengetahui tindakan pencoretan tulisan dan penanda pada koleksi buku terjadi di Perpustakaan FIKOM UNPAD. Hal ini dikarenakan jawaban responden lebih banyak mengacu ke pernyataan setuju.

Tabel 5

Pelipatan halaman tertentu pada koleksi buku

\begin{tabular}{llll}
\hline No. & Kategori jawaban & $\mathbf{f}$ & $\mathbf{\%}$ \\
\hline 1 & Sangat Setuju & 56 & 47,3 \\
2 & Setuju & 43 & 36,7 \\
3 & Netral & 15 & 12,4 \\
4 & Tidak Setuju & 4 & 3,3 \\
5 & Sangat Tidak Setuju & 3 & 0,3 \\
Jumlah & 121 & 100 \\
\hline
\end{tabular}

Sumber: Hasil pengolahan data, 2017

Sesuai tabel 5, diketahui bahwa jawaban responden terhadap pernyataan "Adanya pelipatan halaman tertentu pada koleksi buku" sebanyak 56 responden memilih jawaban sangat setuju, 43 responden memilih jawaban setuju, 15 responden memilih jawaban netral, 4 responden memilih jawaban tidak setuju, dan 3 responden memilih jawaban sangat tidak setuju. Berdasarkan hasil jawaban tersebut, responden mengetahui tindakan pelipatan halaman tertentu pada koleksi buku di Perpustakaan FIKOM UNPAD, hal ini di karenakan jawaban responden lebih banyak mengacu ke pernyataan setuju. 
Tabel 6

Pemanfaatan kartu anggota perpustakaan orang lain untuk meminjam koleksi buku

\begin{tabular}{llll}
\hline No. & Kategori jawaban & f & \% \\
\hline 1 & Sangat Setuju & 63 & 52 \\
2 & Setuju & 35 & 29 \\
3 & Netral & 13 & 11 \\
4 & Tidak Setuju & 6 & 5 \\
5 & Sangat Tidak Setuju & 4 & 3 \\
Jumlah & 121 & 100
\end{tabular}

Sumber: Hasil pengolahan data, 2017

Sesuai tabel 6, diketahui bahwa jawaban responden terhadap pernyataan "Adanya pemanfaatan kartu anggota perpustakaan orang lain untuk meminjam koleksi buku" sebanyak 63 responden memilih jawaban sangat setuju, 35 responden memilih jawaban setuju, 13 responden memilih jawaban netral, 6 responden memilih jawaban tidak setuju, dan 4 responden memilih jawaban sangat tidak setuju. Berdasarkan hasil jawaban tersebut, responden mengetahui tindakan pemanfaatan kartu anggota perpustakaan orang lain untuk meminjam koleksi buku terjadi di Perpustakaan FIKOM UNPAD. Hal ini dikarenakan jawaban responden lebih banyak mengacu ke pernyataan setuju.

Tabel 7

Pengembalian buku yang terlambat

\begin{tabular}{llll}
\hline No. & Kategori jawaban & $\mathbf{f}$ & $\mathbf{0}$ \\
\hline 1 & Sangat Setuju & 59 & 49 \\
2 & Setuju & 47 & 39 \\
3 & Netral & 8 & 6,6 \\
4 & Tidak Setuju & 7 & 5,4 \\
5 & Sangat Tidak Setuju & 0 & 0 \\
Jumlah & 121 & 100 \\
\hline
\end{tabular}

Sumber: Hasil pengolahan data, 2017

Sesuai tabel 7, diketahui bahwa jawaban responden terhadap pernyataan "Adanya pengembalian buku yang terlambat oleh pemustaka" sebanyak 59 responden memilih jawaban sangat setuju, 47 responden memilih jawaban setuju, 8 responden memilih jawaban netral, dan 7 responden memilih jawaban tidak setuju. Berdasarkan hasil jawaban tersebut, responden mengetahui tindakan pengembalian buku secara terlambat pada koleksi terjadi di Perpustakaan FIKOM UNPAD. Hal ini dikarenakan jawaban responden lebih banyak mengacu ke pernyataan setuju. Tri (2005) dalam Listiyani (2010) mengungkapkan bahwa pemustaka yang terlambat dalam mengembalikan koleksi biasanya menggunakan alasan seperti lupa, meminjamkan ke orang lain atau dipinjam orang lain, terselip dan dipergunakan sebagai referensi tugas akhir.

Selain indikator pengetahuan, terdapat juga indikator pemahaman yang diketahui dari pemahaman tentang pengeratan dan membetot halaman, pemahaman perobekan halaman tertentu, pemahaman pengguntingan gambar, pemahaman tentang pencoretan tulisan dan penanda, pemahaman tentang pelipatan halaman tertentu, pemahaman tentang pemanfaatan kartu anggota orang lain, dan pemahaman pengembalian buku yang terlambat dikembalikan.

Tabel 8

Pemahaman tentang pengeratan dan membetot halaman

\begin{tabular}{llll}
\hline No. & Kategori jawaban & f & \% \\
\hline 1 & Sangat Setuju & 59 & 49 \\
2 & Setuju & 38 & 31 \\
3 & Netral & 18 & 15 \\
4 & Tidak Setuju & 6 & 5 \\
5 & Sangat Tidak Setuju & 0 & 0 \\
Jumlah & 121 & 100 \\
\hline
\end{tabular}

Sumber: Hasil pengolahan data, 2017

Sesuai tabel 8, diketahui bahwa jawaban responden terhadap pernyataan "Pemahaman pengeratan dan membetot halaman pada koleksi buku perpustakaan dapat merugikan pemustaka lainnya" 
sebanyak 59 responden memilih jawaban sanngat setuju, 38 responden memilih jawaban setuju, 18 responden memilih jawaban netral, dan 6 responden memilih jawaban tidak setuju. Berdasarkan hasil jawaban tersebut, responden memahami bahwa tindakan pengeratan dan membetot halaman tertentu pada koleksi buku di Perpustakaan FIKOM UNPAD merupakan tindakan yang bisa merugikan pemustaka lain. Hal ini dikarenakan jawaban responden lebih banyak mengacu ke pernyataan setuju. Namun, ada pula beberapa responden yang belum memahami bahwa tindakan ini dapat merugikan pemustaka lainnya.

Tabel 9

Pemahaman tentang perobekan halaman tertentu

\begin{tabular}{llll}
\hline No. & Kategori jawaban & f & \% \\
\hline 1 & Sangat Setuju & 79 & 65,2 \\
2 & Setuju & 35 & 29 \\
3 & Netral & 5 & 4,1 \\
4 & Tidak Setuju & 2 & 1,7 \\
5 & Sangat Tidak Setuju & 0 & 0 \\
Jumlah & 121 & 100 \\
\hline
\end{tabular}

Sumber: Hasil pengolahan data, 2017

Sesuai tabel 9, diketahui bahwa jawaban responden terhadap pernyataan "Pemahaman tentang perobekan pada halaman tertentu koleksi buku" sebanyak 79 responden memilih jawaban sangat setuju, 35 responden memilih jawaban setuju, 5 responden memilih jawaban netral, dan 2 responden memilih jawaban tidak setuju. Berdasarkan hasil jawaban tersebut, responden memahami bahwa tindakan perobekan halaman tertentu pada koleksi buku di Perpustakaan FIKOM UNPAD merupakan tindakan yang bisa merugikan pemustaka lain. Hal ini dikarenakan jawaban responden lebih banyak mengacu ke pernyataan setuju. Namun, ada pula beberapa responden yang belum memahami bahwa tindakan ini dapat merugikan pemustaka lain.

Tabel 10

Pemahaman tentang pengguntingan gambar

\begin{tabular}{llll}
\hline No. & Kategori jawaban & f & $\mathbf{0}$ \\
\hline 1 & Sangat Setuju & 80 & 66,1 \\
2 & Setuju & 35 & 29 \\
3 & Netral & 5 & 4,1 \\
4 & Tidak Setuju & 1 & 0,8 \\
5 & Sangat Tidak Setuju & 0 & 0 \\
Jumlah & 121 & 100 \\
\hline
\end{tabular}

Sumber: Hasil pengolahan data, 2017

Sesuai tabel 10, diketahui bahwa jawaban responden terhadap pernyataan "Pemahaman tentang pengguntingan halaman tertentu pada koleksi buku" sebanyak 80 responden memilih jawaban sangat setuju, 35 responden memilih jawaban setuju, 5 responden memilih jawaban netral, dan 1 responden memilih jawaban tidak setuju. Berdasarkan hasil jawaban tersebut, responden memahami bahwa tindakan pengguntingan gambar pada koleksi buku di Perpustakaan FIKOM UNPAD merupakan tindakan yang bisa merugikan pemustaka lain. Hal ini dikarenakan jawaban responden lebih banyak mengacu ke pernyataan setuju. Namun, ada pula beberapa responden yang belum memahami bahwa tindakan ini dapat merugikan pemustaka lain.

Tabel 11

Pemahaman tentang pencoretan tulisan dan penanda

\begin{tabular}{llll}
\hline No. & Kategori jawaban & f & \% \\
\hline 1 & Sangat Setuju & 50 & 42,1 \\
2 & Setuju & 43 & 35,1 \\
3 & Netral & 17 & 14 \\
4 & Tidak Setuju & 10 & 8 \\
5 & Sangat Tidak Setuju & 1 & 0,8 \\
Jumlah & 121 & 100 \\
\hline
\end{tabular}

Sumber: Hasil pengolahan data, 2017

Sesuai tabel 11, diketahui bahwa jawaban responden terhadap pernyataan "Pemahaman tentang pencoretan tulisan 
dan penanda pada koleksi buku" sebanyak 50 responden memilih jawaban sangat setuju, 43 responden memilih jawaban setuju, 17 responden memilih jawaban netral, 10 responden memilih jawaban tidak setuju, dan 1 responden memilih jawaban sangat tidak setuju. Berdasarkan hasil jawaban tersebut, sebagian besar responden memahami bahwa tindakan pemberian coretan tulisan dan penanda pada koleksi buku di Perpustakaan FIKOM UNPAD merupakan tindakan yang bisa merugikan pemustaka lain. Hal ini dikarenakan jawaban responden lebih banyak mengacu ke pernyataan setuju. Namun, ada pula beberapa responden yang belum memahami bahwa tindakan ini dapat merugikan pemustaka lain.

Tabel 12

Pemahaman tentang pelipatan halaman tertentu

\begin{tabular}{llll}
\hline No. & Kategori jawaban & f & \% \\
\hline 1 & Sangat Setuju & 42 & 35 \\
2 & Setuju & 40 & 33 \\
3 & Netral & 29 & 24 \\
4 & Tidak Setuju & 9 & 7,2 \\
5 & Sangat Tidak Setuju & 1 & 0,8 \\
Jumlah & 121 & 100 \\
\hline
\end{tabular}

Sumber: Hasil pengolahan data, 2017

Sesuai tabel 12, diketahui bahwa jawaban responden terhadap pernyataan "Pemahaman tentang pelipatan halaman tertentu pada koleksi buku" sebanyak 42 responden memilih jawaban sangat setuju, 40 responden memilih jawaban setuju, 29 responden memilih jawaban netral, 9 responden memilih jawaban tidak setuju dan 1 responden memilih jawaban sangat tidak setuju. Berdasarkan hasil jawaban tersebut, sebagian besar responden memahami bahwa tindakan pelipatan halaman pada koleksi buku di Perpustakaan FIKOM UNPAD merupakan tindakan yang bisa merugikan pemustaka lain. Hal ini dikarenakan jawaban responden lebih banyak mengacu ke pernyataan setuju. Namun, ada pula beberapa responden yang belum memahami bahwa tidakan ini dapat merugikan pemustaka lain.

Tabel 13

Pemahaman tentang pemanfaatan kartu anggota orang lain

\begin{tabular}{llll}
\hline No. & Kategori jawaban & $\mathbf{f}$ & $\mathbf{0}$ \\
\hline 1 & Sangat Setuju & 32 & 26,4 \\
2 & Setuju & 34 & 28,2 \\
3 & Netral & 30 & 24,7 \\
4 & Tidak Setuju & 18 & 14,9 \\
5 & Sangat Tidak Setuju & 7 & 5,8 \\
& Jumlah & 121 & 100 \\
\hline
\end{tabular}

Sumber: Hasil pengolahan data, 2017

Sesuai tabel 13, diketahui bahwa jawaban responden terhadap pernyataan "Pemahaman tentang pemanfataan kartu anggota orang lain untuk meminjam koleksi buku merupakan tindakan yang salah" sebanyak 32 responden memilih jawaban sangat setuju, 34 responden memilih jawaban setuju, 30 responden memilih jawaban netral, 18 responden memilih jawaban tidak setuju, dan 7 responden memilih jawaban sangat tidak setuju. Berdasarkan hasil jawaban tersebut, sebagian besar responden memahami bahwa tindakan memanfaatkan kartu anggota perpustakaan orang lain baik secara sengaja maupun tidak sengaja untuk meminjam koleksi buku di Perpustakaan FIKOM UNPAD merupakan tindakan yang bisa merugikan pemustaka lain. Hal ini dikarenakan jawaban responden lebih banyak mengacu ke pernyataan setuju. Namun, ada pula beberapa responden yang belum memahami bahwa tindakan ini dapat merugikan pemustaka lain. Jawaban netral responden mengacu pada jawaban tidak tahu jika terjadi atau tidak setuju pada pernyataan tapi ragu-ragu. 
Tabel 14

Pemahaman pengembalian buku yang terlambat dikembalikan

\begin{tabular}{llll}
\hline No. & Kategori jawaban & f & $\mathbf{0}$ \\
\hline 1 & Sangat Setuju & 58 & 48 \\
2 & Setuju & 44 & 36,3 \\
3 & Netral & 16 & 13,2 \\
4 & Tidak Setuju & 3 & 2,5 \\
5 & Sangat Tidak Setuju & 0 & 0 \\
& Jumlah & 121 & 100 \\
\hline
\end{tabular}

Sumber: Hasil pengolahan data, 2017

Sesuai tabel 14, diketahui bahwa jawaban responden terhadap pernyataan "Pemahaman pengembalian buku yang terlambat dikembalikan" sebanyak 58 responden memilih jawaban sangat setuju, 44 responden memilih jawaban setuju, 16 responden memilih jawaban netral, dan 3 responden memilih jawaban tidak setuju. Berdasarkan hasil jawaban tersebut, sebagian besar responden memahami bahwa tindakan pengembalian buku secara terlambat pada koleksi di Perpustakaan FIKOM UNPAD merupakan tindakan yang bisa merugikan pemustaka lain. Hal ini dikarenakan jawaban responden lebih banyak mengacu ke pernyataan setuju. Namun, ada pula beberapa responden yang belum memahami bahwa tindakan ini dapat merugikan pemustaka lain.

Tabel 15

Rangkuman hasil kategori dan garis kontinum

\begin{tabular}{llll}
\hline No. & Pernyataan & Kategori & Garis kontinum \\
\hline 1 & Pengetahuan & Sedang & 281 \\
2 & Pemahaman & Tinggi & 342 \\
3 & Kognitif & Tinggi & 311 \\
\hline
\end{tabular}

Sumber: Hasil penelitian, 2017

Secara kumulatif, indikator pengetahuan berada pada kategori sedang mendekati tinggi dengan perolehan presentase $54,5 \%$, dan berdasarkan garis kontinum berada pada angka 281 yang masuk ke dalam kategori sedang mendekati tinggi. Untuk indikator pemahaman berada pada kategori tinggi dengan perolehan presentase $82,7 \%$, dan garis kontinum berada pada angka 342 yang masuk ke dalam kategori tinggi. Berdasarkan data di atas, aspek kognitif pemustaka berada pada kategori tinggi dengan perolehan presentase $58 \%$, dan garis kontinum berada pada angka 311 yang masuk ke dalam kategori tinggi. Aspek kognitif pemustaka pada tindakan vandalisme dapat dikatakan baik (favorable).

\section{SIMPULAN}

Berdasarkan hasil penelitian yang telah dilakukan maka dapat diambil simpulan bahwa para pemustaka dalam aspek kognitif, mengetahui tindakan pencoretan tulisan atau penanda, pelipatan halaman, pemanfaatan kartu anggota perpustakaan orang lain dan pengembalian buku secara terlambat menjadi tindakan vandalisme yang ditemukan pemustaka di Perpustakaan FIKOM UNPAD, sedangkan tindakan pengeratan dan membetot halaman, perobekan halaman dan pengguntingan gambar tidak ditemukan oleh pemustaka. Kemudian, pemustaka memahami bahwa tindakan vandalisme merupakan tindakan yang dapat merugikan pemustaka lainnya. Sedangkan pada aspek kognitif pemustaka pada tindakan vandalisme berada pada kategori tinggi dan baik (favorable). Artinya, pemustaka mempunyai pengetahuan dan pemahaman yang mendukung terkait tindakan vandalisme. Pemustaka mengetahui dan memahami betul bahwa tindakan vandalisme terhadap koleksi yang ada di perpustakaan merupakan tindakan yang dapat merusak fisik koleksi bahkan dapat menghilangkan kandungan informasi koleksi.

\section{DAFTAR PUSTAKA}

Adekunle, F. A., Adekunjo, O. A., \& 
Unuabor, S. O. (2018). Theft and vandalism: Effect and control mechanism on information resources in academic libraries in Osun State, Nigeria. IOSR Journal Of Humanities And Social Science, 23(7), 71-78. Retrieved from http:/ / www.iosrjournals.org/iosrjhss/papers/Vol. 23 Issue7/Version9/J2307097178.pdf

Andina, D. M. (2016). Hubungan persepsi siswa terhadap citra sekolah dengan minat belajar di SMK X Yogyakarta (Skripsi). Universitas Gadjah Mada, Yogyakarta.

Astriyana. (2017). Perpustakaan sekolah sebagai pusat sumber belajar (Skripsi). Universitas Ahmad Dahlan, Yogyakarta. Retrieved from http://eprints.uad.ac.id/5247/1/ASTR IYANA-1300005178-MAKALAH PERPUSTAKAAN SEBAGAI PUSAT SUMBER BELAJAR.pdf

Damayanti, Sukaesih, \& Rainathami, H. (2015). Upaya pencegahan penyalahgunaan koleksi Perpustakaan KEMENDIKBUD. Kajian Informasi $\mathcal{E}$ Perpustakaan, 3(2), 147-154. https://doi.org/10.24198/jkip.v3i2.997 7.g4694

Efriza, E., Agustini, N., \& Saepudin, E. (2015). Strategi manajemen perpustakaan dalam menghadapi vandalisme. Jurnal Kajian Informasi $\mathcal{E}$ Perpustakaan, 3(1), 43-70. https://doi.org/10.24198/jkip.v3i1.948 8

Kisti, H. H., \& Fardana N., N. A. (2012). Hubungan antara self efficacy dengan kreativitas pada siswa SMK. Jurnal Psikologi Klinis Dan Kesehatan Mental, 1(2), 52-58. Retrieved from
http://journal.unair.ac.id/JPKK@therelationship-between-self-efficacywith-creativity-on-vocational-highschool-students-article-6999-media-51category-10.html

Listiyani. (2010). Penyalahgunaan Koleksi Perpustakaan: Studi kasus di Perpustakaan Umum Yayasan LIA Pramuka (Skripsi). Universitas Indonesia, Depok. Retrieved from http:/ / lib.ui.ac.id/file?file=digital/201 60877-RB13L199p-Penyalahgunaan koleksi.pdf

Muhammad, A. (2018). Pengaruh kompensasi terhadap motivasi kerja di PT Hamatetsu Indonesia. Jurnal UNSIKA, 3(1), 426-433. Retrieved from https://journal.unsika.ac.id/index.php /value/article/view/1539/1360

Rahmawati, G. N. (2014). Perilaku vandalisme pemustaka di Perpustakaan Universitas Islam Negeri (UIN) Syarif Hidayatullah Jakarta (Skripsi). UIN Syarif Hidayatulloh. Retrieved from http:/ / repository.uinjkt.ac.id/dspace/ bitstream/123456789/29370/3/GUWI DO NUR RAHMAWATI - FAH.pdf

Rakhmat, J. (2009). Metode penelitian komunikasi. Bandung: Remaja Rosdakarya.

Reitz, J. M. (2014). Online dictionary for library and information science. Retrieved November 23, 2018, from https:/ / www.abcclio.com/ODLIS/odlis_m.aspx

Winiratih, A. (2016). Pengaruh iklan televisi dan event sponshorsip terhadap brand image Bakmi Mewah (Skripsi). Universitas Multimedia Nusantara, Tangerang. Retrieved from http://kc.umn.ac.id/203/3/BAB II.pdf 